\title{
Biases and imperatives in handling medical technology
}

Author: Bjørn Hofmann, PhD

Affiliations:

The Centre of Medical Ethics at the University of Oslo, Norway and

Institute for the Health Sciences at the Norwegian University of Science and Technology, Gjøvik, Norway

Corresponding address: Bjørn Hofmann,

Centre for Medical Ethics

University of Oslo

PO Box 1130, Blindern

N-0318 Oslo, Norway

b.m.hofmann@medisin.uio.no

Number of pages: 16

Number of words: 4500 (without references), 8000 with references

Number of tables: 1

Number of figures: 1

Number of references: 128 for review, 40 for publication

\section{Declarations}

The manuscript is sent exclusively to you, has not been previously published elsewhere, and is not currently under review elsewhere.

I certify that there is no conflict of interest in relation to this manuscript, and there are no financial arrangements or arrangements with respect to the content of this manuscript with any companies or organizations.

Ethics approval and consent to participate: Not relevant for this study

Availability of data and material: List of analyzed literature is presented in article. Database of screened literature is available on request.

Funding: No special funding for this research

Authors' contributions: One author.

\section{Acknowledgement}

I am most grateful to Paul Slovic for directing my attention to the work of Michael Mazarr. Some elements of this paper have been presented and discussed with the participants of the Priorities 2018 conference in Linköping in Sweden.

I am the sole author of this manuscript. The manuscript is sent exclusively to you, has not been previously published elsewhere, and is not currently under review elsewhere.

I certify that there is no conflict of interest in relation to this manuscript, and there are no financial arrangements or arrangements with respect to the content of this manuscript with any companies or organizations.

Some of the examples given are experienced by the author himself as part of his previous job as a health technology manager at a hospital trust in Norway.

Key words: medical technology, health care, bias, imperative, rationality 


\section{Biases and imperatives in handling medical technology}

\section{Abstract:}

\section{Objectives:}

For a long time key actors in health care have conceived of medical technology as a rational science-based means to obtain specific human goals, such as reducing suffering and increasing health. However, this appears paradoxical as medical technologies are handled in ways that appear non-rational by the standards of the field itself, e.g., by implementing nonefficient technologies and by not abandoning harmful or low-value technologies. The objective of this article is to investigate this apparent paradox. How can it be explained? Accordingly, the research question is: What biases and imperatives are involved in the handling of medical technology that counter and hamper what is conceived of as rational handling of such technology in medicine and health care?

\section{Methods:}

Kahneman's framework of System 1 and 2 modes of thinking from cognitive psychology is applied and combined with Mazarr's analysis of imperatives in order to study and develop a typology of irrational implementation of technology. Examples from health care are found by targeted searches in PubMed.

\section{Results:}

Health policy on technology assessment and implementation is based on measures, such as safety, effectiveness, and efficiency. Nevertheless, a range of technologies are implemented and used without obtaining such goals. This can be explained by, a range of affective biases, such as the Identifiability Effect, Affective Forecasting, and Impact bias, as well as cognitive biases, such as the Focusing Illusion, Prominence Effect, Status Quo Bias, Endowment Effect, Availability Heuristics, Anchoring Effect and others. Various imperatives also contribute to this, such as Positive feedback loops, Imperative of Action, Technology Placebo Effect, Imperative of Knowledge, the Boys and Toys Effect and others. Examples illustrate how all of these effects can distort rational technology implementation and policy.

\section{Conclusion:}

We need to include biases and imperatives in our theories and our strategies to handle medical technologies. Believing and acting as if we implement and use technology in health care as external means to our internal goals may be treacherous. Understanding technology indeed includes understanding of ourselves.

\section{Highlights:}

- Medical technology is handled contrary to explicit principles, elaborate systems, and foundational documents for health technology assessment, priority setting, as well as policy and decision making.

- One reason for such non-rational handlings of medical technologies is biases and imperatives.

- Accordingly, we need to include biases and imperatives in our theories of medical technologies as well as in our efforts to handle such technologies.

Key words: medical technology, health care, bias, imperative, rationality 


\section{Introduction}

Technology has been conceived of as a rational science-based means to obtain specific human goals. Nowhere has this been as dominant as in medicine and health care, where technology is considered to be a powerful means for preventing, detecting, and treating disease as well as promoting health. This rationalistic conception of technology implementation is still very much viable in medicine and health care (1). It is expressed in basic and guiding documents in health technology assessment (HTA), priority setting, and health policy making (2-7). Contrary to what is widely recognized in science and technology studies (STS) (8-11) and in technology assessment (TA, in general), seeing technology as value-laden has not yet become widespread within health technology assessment (HTA) and policy making (1, 12-14). Given these strong aspirations for rational handling of technology in medicine and health care it appears paradoxical that technology frequently is implemented without evidence (15-17) and sometimes applied even when it is harmful (18). The same goes for the extensive use of low-value health technologies (19-24), where "low-value technology" is defined as failing to improve health but increasing cost (25). In particular, 1350 specific low-value technologies have been identified (26). There is an outspoken resistance to disinvestment of such technologies (27), even when it hampers the implementation of (expensive) high-value technologies. Why is this so? This is the key question of this article.

There may of course be a wide range of explanations for the implementation and use of lowvalue technology. This article will only study two specific factors that have not been widely scrutinized: biases and imperatives in the implementation of medical technologies.

Accordingly, the research question of this article is: What biases and imperatives are involved in the handling of medical technology that counter and hamper what is conceived of as rational handling of such technology in medicine and health care? With "handling” I refer to assessment, implementation, use, reassessment, and/or disinvestment (or decommissioning) of technology. With "rational handling of technology" I refer to what is expressed as justified handling in foundational documents for HTA, priority setting, and health policy making. Bias here refers to an unwarranted or disproportionate weight in favor of or against a specific technology. Imperative here means following "an intensely felt requirement or obligation" (28) to take specific action (with respect to technology) without closer analysis or rigorous thought.

\section{Approach (Methods)}

As non-rational behavior is extensively described and addressed in cognitive psychology and behavioral economics, this study will apply the influential framework developed by Daniel Kahneman and colleagues. In particular the System 1 and System 2 modes of thinking will be applied, where non-rational aspects refer to what has been defined as non-analytical, intuitive, fast, affective, or System-1 reasoning. This is contrasted with analytic, slow, deliberative, or System-2 reasoning $(29,30)$, which corresponds to the preferred rationality in HTA, priority setting and health policy making.

However, as some of the phenomena to be studied are not covered by System 1 and System 2 thinking, or lie at their intersection, the study supplements this analysis with the framework of Michael Mazarr including imperatives. Imperatives are actions that are felt needed (independent of or due to dim outcomes). They are immediate reflections of long-established doctrine or belief, and can be rooted in deontology (28). Imperatives are frequently referred to in the literature on medical technology (31-38). However, it is seldom studied in detail and classified.

Hence, this study will analyze biases and imperatives hampering rational (System-2-based) handling of technology, as declared in HTA, priority setting, and in health policy documents. 
The typology will follow the traditional (but not always clear and coherent) division between cognitive and affective biases.

To find relevant studies in the field, US National Library of Medicine, National Institutes of Health (PubMed) was used. The search was performed January 202019 with the search string ("health technology assessment"[All Fields] OR ("Health Technol Assess"[Journal] OR "hta"[All Fields])) AND (("bias"[MeSH Terms] OR "bias"[All Fields]) OR imperative[All Fields]) AND (deliberation[All Fields] OR (priority[All Fields] AND setting[All Fields]) OR ("health policy"[MeSH Terms] OR ("health"[All Fields] AND "policy"[All Fields]) OR "health policy"[All Fields])). 94 references were identified, but only 5 were relevant for the topic, judged by title and abstract.

In order to find examples from health care a series of targeted searches in PubMed are performed. Search strings were tailored to specific technologies and biases/imperatives and snowballing technique was applied. The search was stopped when a relevant example was found that adequately illustrates the phenomenon.

The included studies were analyzed with directed content analysis (39). In the search for biases and imperatives the texts were searched for non-rational handling of technologies. In search for examples, texts were searched for the specific biases and imperatives and how they could explain the phenomena. Only biases and imperatives relevant for medicine and health care and where illuminating examples can be provided are included.

\section{Results: Non-rational aspects of handling medical technology}

Let us start with investigating whether and how some of the well-known affective biases from the literature apply to the handling of medical technology before we move to the cognitive biases.

\section{Affective biases and emotional inclinations}

Table 1 gives an overview of affective biases, explanations and examples, while the text below provides more information about the biases.

Table 1 Affective biases identified in the handling medical technologies.

\begin{tabular}{|l|l|l|}
\hline Bias & Explanation & Example (reference) \\
\hline Identifiability effect & $\begin{array}{l}\text { Identified diseases, groups, or } \\
\text { persons call for attention and } \\
\text { empathy }\end{array}$ & $\begin{array}{l}\text { Prostate cancer screening } \\
\text { Mammography screening } \\
\text { Angelina Jolie }\end{array}$ \\
\hline Affective forecasting & $\begin{array}{l}\text { One's emotional state and } \\
\text { conception of technology is } \\
\text { projected to future events. }\end{array}$ & $\begin{array}{l}\text { Swan-Ganz catheters } \\
\text { Thyroid cancer screening } \\
\text { Pulse-oximetry }\end{array}$ \\
\hline $\begin{array}{l}\text { Aversion to risk } \\
\text { Aversion to ambiguity }\end{array}$ & $\begin{array}{l}\text { Fear of missing something } \\
\text { Fear of uncertainty and ignorance }\end{array}$ & $\begin{array}{l}\text { Excessive laboratory tests } \\
\text { Futile imaging }\end{array}$ \\
\hline Technology optimism & $\begin{array}{l}\text { Strong belief in technology as a } \\
\text { problem solver and symbol of } \\
\text { progress }\end{array}$ & CT, MRI, robotic surgery \\
\hline
\end{tabular}

Some technologies are implemented because they are specialized and targeted to specific diseases, groups, or persons (independent of the outcome of identifying the condition). This effect has been called the Identifiability effect. For example, the prostate-specific antigen test (PSA-test) has made it possible to identify a condition indicating a risk for prostate cancer. Although the effectiveness of the test for reducing prostate cancer mortality is low, and the treatment can be harmful $(40,41)$, the test is widely implemented and used. This is because 
identification gives importance. The same phenomenon can be observed in mammography screening. While there is broad agreement that women's health has been neglected, the balance of benefits and harms of screening is highly controversial $(42,43)$. A similar example is Angelina Jolie, who through her personal story promoted preventive genetic testing (44). This effect is related to what has been called "bias towards identified victims" (45) and "the singularity effect” (46).

Another observed phenomenon in health care is that the benefits of technologies are frequently overestimated while risks may be downplayed.. Swan-Ganz catheters, cardiotocographs, pulse-oxymeters and many other technologies were proposed to have great benefits, while their outcomes have been meager $(47,48)$. With thyroid cancer screening severe concequences of overdiagnosis was ignored for many years (49). The tendency to overestimate benefits (and underestimate risks) relates to what has been called Affective forecasting, where one's emotional state and conception of technology is projected to future events (50).

One specific type of Affective forecasting is Impact bias, i.e., the tendency to overestimate the impact of a future event (51). For example, in health care various forms of information and communication technology (ICT) have repeatedly and forcefully been launched to solve a wide range of the challenges in health care, without by far fulfilling its promises. Most lately this is evident with BigData and Artificial Intelligence (52-56).

Handling technologies by aversions, is yet another affective bias. Aversions to dangers or uncertainties may make us implement and use low-value technologies. Extra blood tests and excessive imaging may be extensive even though they will not increase our knowledge or change the clinical pathway, are but two examples (57-59). We tend to test because we are afraid of missing something and to treat because we are uncertain of how to handle the risk. These tendencies correspond to biases such as Aversion to Risk and Aversion to Ambiguity (60).

Technology optimism is yet another kind of affective bias where we assess and implement technologies based on enthusiasm and strong belief in technology. A wide range of medical technologies have been implemented based on optimism and long before there was strong evidence of their effectiveness and efficiency, such as CT, MRI, robotic surgery etc.

\section{Cognitive biases}

Corresponding to what may be classified as affective biases, there are also a range of cognitive biases influencing the handling of medical technology. Table 2 gives a brief overview of such biases.

Table 2 Cognitive biases identified in the handling medical technologies.

\begin{tabular}{|l|l|l|}
\hline Bias & Explanation & Example (reference) \\
\hline $\begin{array}{l}\text { Focusing illusion } \\
\text { Prominence effect }\end{array}$ & $\begin{array}{l}\text { Focusing on specific aspects } \\
\text { Letting certain gain } \\
\text { prominence }\end{array}$ & $\begin{array}{l}\text { Assessing diagnostic technologies } \\
\text { based on technical specifications } \\
\text { rather than patient outcomes }\end{array}$ \\
\hline Status Quo Bias & $\begin{array}{l}\text { Preserving the current state of } \\
\text { affairs } \\
\text { Clinging to existing } \\
\text { technologies beyond reason } \\
\text { Loss aversion }\end{array}$ & $\begin{array}{l}\text { Not abandoning low-value } \\
\text { implechologies and not } \\
\text { implenting high-value } \\
\text { technologies }\end{array}$ \\
\hline $\begin{array}{l}\text { Anticipated Decision } \\
\text { Regret; “Better safe } \\
\text { than sorry" }\end{array}$ & $\begin{array}{l}\text { Implementing and using } \\
\text { technology out of fear of what } \\
\text { would happen if we did not }\end{array}$ & $\begin{array}{l}\text { Extra laboratory tests } \\
\text { Excessive x-rays }\end{array}$ \\
\hline Anchoring Effect & Relying on initial information & $\begin{array}{l}\text { Basing deliberations on initial and } \\
\text { unwarrantedly positive studies }\end{array}$ \\
\hline
\end{tabular}




\begin{tabular}{|l|l|l|}
\hline $\begin{array}{l}\text { Availability } \\
\text { Heuristics }\end{array}$ & $\begin{array}{l}\text { If a technology is available, it } \\
\text { will be used }\end{array}$ & $\begin{array}{l}\text { Imaging services } \\
\text { Laboratory services }\end{array}$ \\
\hline
\end{tabular}

Handling health technologies is notoriously complex, and taking all aspects into account is very demanding. When assessing and implementing technologies, we tend to focus on specific features, ignoring other and important aspects. For example, when assessing diagnostic technologies we tend to focus on accuracy data (such as test sensitivity and specificity) and not on what matters for patients, i.e., diagnostic impact and subsequent therapeutic outcomes (61). This can be related to what has been called the Focusing Illusion according to which we tend to focus too much on certain details of an event, ignoring other factors (62). It is also related to the Prominence effect, according to which one dominant factor determines the decision-makers' preferences. We may focus on the increased spatial resolution of a diagnostic ultrasound device, but not on what this means for patients health (61). For example, the complexity of assessing and implementing health technology may be eased by highlighting one (or a few) aspects. This is most visible in the assessment and implementation of diagnostic technologies, where technical specifications are at the fore of decision-making while outcomes from subsequent treatments and complexity are discounted (63-65). However, such effects hamper rational handling of technology as it can result in what has been called the opportunity cost neglect (66). We tend to ignore the alternative uses of the resources spent for a poorly assessed technology.

Another relevant bias is the Status Quo Bias, which describes the irrational preference for an option only because it preserves the current state of affairs (67). This may result from people's aversion to change (conservativism), making them avoiding changing practice (60). For example a lot of technologies may be used although they are of low-value (26), while new high-value technologies may not be implemented. Accordingly, the status quo bias may hamper rational handling of technology.

The Status Quo Bias is associated with the Endowment Effect, according to which we tend to overvalue what we already have got compared to alternatives. In economic terms: "the fact that people often demand much more to give up an object than they would be willing to pay to acquire it" (68). Accordingly, the health technology that we have implemented and used for a long time, , and which constitutes our professional identity, tends to be valued higher than other technologies; even when there is evidence that the alternative technology is better. The Endowment Effect in turn is related to an asymmetry of value expressed as Loss Aversion, according to which we feel uncomfortable with loosing what we have. In economic terms "the disutility of giving up an object is greater that the utility associated with acquiring it” (68). This appears to be happening in handling medical technology. As already mentioned, disinvesting old and low-value technologies seems to be much more difficult than to invest and implement new technologies $(27,69-73)$.

Two other related effects are anticipated decision regret (74) and better safe than sorry (75). The fear of doing too little appears to be greater than the fear of doing too much. This "fear asymmetry") may drive defensive medicine and what has been called the "popularity paradox," i.e., that people think they are saved by extra diagnostic tests while they in fact result in overdiagnosis ${ }^{1}$ and overtreatment $(76,77)$. The better-safe-than-sorry-bias is prevalent both in diagnostics $(78)$ and therapeutics $(79,80)$

Yet another cognitive biases that tends to be observable in handling medical technology is the Anchoring Effect, where the decision-maker tends to rely too much on initial information, and ignores more hard to get high quality evidence (60). Initial studies may be unwarrantedly

\footnotetext{
${ }^{1}$ Overdiagnosis occurs when we find conditions that will not develop into symptoms or disease if left untreated. The problem is that we do not know in advance which condition will develop to something harmful or not.
} 
positive (81) and may dominate deliberations on technologies. This is related to the Focusing illusion.

Correspondingly, Availability Heuristics may make diagnostics or treatments implemented and used primarily because they are available. This phenomenon is easily observed in imaging, where there is a significant association between available imaging technology and the number of examinations performed $(82,83)$. Despite awareness of this effect, which has been coined "Roemer's law," very few effective measures have been taken to counter this effect. Hence, despite awareness of "irrational aspects" of handling technology, it has turned out to be difficult to neutralize this effect. This gives us reasons to believe that some of the biases we have in handling technology in medicine and health care are deeply ingrained in human psychology.

The problem with these (and many other) affective and cognitive biases is that they tend to hamper what is considered to be rational handling of technology by the field of medicine and health-care itself.

\section{Imperatives}

However, there are many other non-rational ways of handling of technology that do not fall under the concept of bias. In line with the framework of Mazarr, these can be scrutinized as imperatives (although they may be called biases). Table 3 gives an overview over such imperatives apparent in handling medical technology.

Table 3 Imperatives identified in the handling medical technologies.

\begin{tabular}{|c|c|c|}
\hline Imperative & Explanation & Example (reference) \\
\hline Roemer's law & $\begin{array}{l}\text { If a technology is available, it } \\
\text { will be used }\end{array}$ & $\begin{array}{l}\text { Imaging technologies } \\
\text { Robotic surgery }\end{array}$ \\
\hline $\begin{array}{l}\text { Progress Bias } \\
\text { Adoption Addiction }\end{array}$ & $\begin{array}{l}\text { Implementing technologies } \\
\text { because they symbolize } \\
\text { novelty and progress }\end{array}$ & $\begin{array}{l}\text { ICT in health care } \\
\text { Xeno-transplantation } \\
\text { AI, BigData, gene editing }\end{array}$ \\
\hline Complexity Bias & $\begin{array}{l}\text { Advanced systems are thought } \\
\text { of as better than simple }\end{array}$ & Pulse oximetry \\
\hline Extension Bias & More is better than little & Overdiagnosis, overtreatment \\
\hline $\begin{array}{l}\text { Asymmetry of risks } \\
\text { and benefits }\end{array}$ & $\begin{array}{l}\text { Overestimating benefits and } \\
\text { underestimating risks }\end{array}$ & $\begin{array}{l}\text { Screening (e.g., thyroid, prostate } \\
\text { and breast cancer) }\end{array}$ \\
\hline $\begin{array}{l}\text { Positive feedback } \\
\text { loops }\end{array}$ & $\begin{array}{l}\text { Detecting and treating milder } \\
\text { cases gives better results }\end{array}$ & $\begin{array}{l}\text { Overdiagnosis } \\
\text { Overtreatment }\end{array}$ \\
\hline Prestige bias & $\begin{array}{l}\text { Diseases and specialties using } \\
\text { advanced technologies have } \\
\text { high prestige }\end{array}$ & $\begin{array}{l}\text { Intensive Care Units } \\
\text { Anesthesiology }\end{array}$ \\
\hline Imperative of Action & $\begin{array}{l}\text { It is better to do something } \\
\text { than not to do anything }\end{array}$ & $\begin{array}{l}\text { Overtreatment of patients at the } \\
\text { end of life }\end{array}$ \\
\hline $\begin{array}{l}\text { Technology Placebo } \\
\text { Effect }\end{array}$ & $\begin{array}{l}\text { Strong belief in technology } \\
\text { influences outcome }\end{array}$ & $\begin{array}{l}\text { Laser surgery for occluded cardiac } \\
\text { arteries }\end{array}$ \\
\hline $\begin{array}{l}\text { Imperative of } \\
\text { Knowledge }\end{array}$ & $\begin{array}{l}\text { It is better to know than not to } \\
\text { know }\end{array}$ & $\begin{array}{l}\text { Excessive (biochemical) testing } \\
\text { and imaging }\end{array}$ \\
\hline $\begin{array}{l}\text { Imperative of the } \\
\text { Primus }\end{array}$ & $\begin{array}{l}\text { Early detection is better than } \\
\text { late detection }\end{array}$ & Screening \\
\hline Competency Effect & $\begin{array}{l}\text { Procedures to gain competency } \\
\text { (and not to help patients) }\end{array}$ & Surgical procedures (endoscopy) \\
\hline Multiple & Replacing a technology several & Ultrasound machines \\
\hline
\end{tabular}




\begin{tabular}{|l|l|l|}
\hline Replacements & times (due to obsolescence) & Monitoring devices \\
\hline White Elephants & $\begin{array}{l}\text { Technologies implemented to } \\
\text { keep employees happy }\end{array}$ & $\begin{array}{l}\text { Electron microscope } \\
\text { Angiography laboratories }\end{array}$ \\
\hline Boys and Toys Effect & $\begin{array}{l}\text { Implementing technologies } \\
\text { because they are cool }\end{array}$ & Robotic surgery \\
\hline
\end{tabular}

One such imperative has been called Roemer's law, according to which provided services will be used independent of their efficacy, i.e., "a built bed is a filled bed,"(84). The imperative is that whenever a technology is implemented, it must be used. This is frequently observed in the implementation of advanced imaging (MRI, CT, PET) as well as in therapies (e.g., robotic surgery) and has been related to supply-sensitive services (85) and supplierinduced demand (86).

Moreover, according to what has been called the Progress Bias we experience a strong propensity to promote what is considered to be progressive (87-89). A wide range of technologies have been promoted because of their progressiveness: neural networks, xenotransplantation, artificial intelligence, BigData, gene editing, and precision medicine. But also more ordinary hospital-based systems, such as picture archiving and communication systems (PACS) have been promoted and implemented without proper assessment (90, 91). Although one might think that a strong belief in progress would promote transition, eliminating old technologies when implementing new ones, there seems to be an accumulative effect in practice. We tend to think that science in general and medicine in particular progresses by adding new technologies and services, not by disposing, reducing or removing old ones. Expansion and accumulation appears as part and parcel of progress. Related to the Progress Bias one can observe very strong tendency to expect positive outcomes of advanced technologies and a strong urge to adopt new technologies. This is sometimes called Adoption Addiction (92, 93) (94). This directs the handling of technologies towards implementing and applying technologies and is related to other phenomena such as "denial of the need for disinvestment" (95). It also advances the use of technology for other purposes than intended without documentation of outcomes. Diagnostic imaging is but one example, where technologies are adopted beyond justification (96). In imaging, technologies that are developed to detect somatic disease, such as CT, MRI, and PET, are used to treat mental conditions, such as health anxiety, or to confirm health rather than detecting disease (97-99).

Another imperative can be called Complexity Bias, which denotes a tendency to think that advanced systems and technologies are better than simple ones. For example using pulse oximetry (a light-based system for measuring blood oxygenation) is considered to be better than observing the wounds or skin of the patient, although evidence for this is wanting (47, 48). Although a great number of advanced technologies identified as low-value care are (26), and it counters our intuition that hi-tech services could be ineffective, inefficient, or even harmful. Such tendencies may undermine rational handling of technology in medicine and health care.

Another and related imperative is Extension Bias, which is a tendency to think that more is better than little (100). This can be observed in the imperative of testing ("more testing is better than less") as well as in the imperative of action (described in more detail below). While there are many examples of where more diagnostics and more treatment is good, lessons on overdiagnosis and overtreatment has learned us that this is no general rule (101). Extension bias certainly challenges what is conceived of as rational handling of medical technology. However, any measures to restrict extensive use of technology breaks with basic intuitions that more is good. This imperative stems from the confusion of quantity and quality and is based on the reasoning from is to ought ( "the naturalistic fallacy"). This imperative 
finds support in metaphorical theory (102), which explains how we have an ingrained tendency to think that more is good.

Additionally, we tend to understand risks and benefits in very unbalanced and biased ways $(103,104)$. Accordingly, there is an imperative stemming from the Asymmetry of risks and benefits. Technologies and health services may not be assessed in an unengaged way (105). The risks of low-value technologies may be underestimated while the benefits may be overestimated, framing the handling of medical technology. Again, the eager to adopt new technologies and the hesitance (or in some cases, resistance) to disinvest or decommissioning is a good example.

Yet another imperative can be observed as Positive feedback loops. For example, increasing the accuracy of diagnostic tests, e.g., by increasing the spatial resolution of an imaging technology, may lead to the detection of more cases. Finding more cases increases the intensity of testing, in turn increasing the number of cases detected. At the same time increased accuracy results in finding more milder cases. However, when treating milder cases this increases the success rate $(99,101,106)$, justifying trying to increase the accuracy even further. Any objections to this experience of success appear counterintuitive, "irrational," and regressive. However, although it may lead to early detection and avoidance of disease and death, it may as well result in overdiagnosis, overtreatment, and harm. Hence, the Asymmetry of risks and benefits enhances the Positive feedback loops. See Figure 1.

Figure 1 Feedback loop in handling diagnostic technology. Adapted from (15).

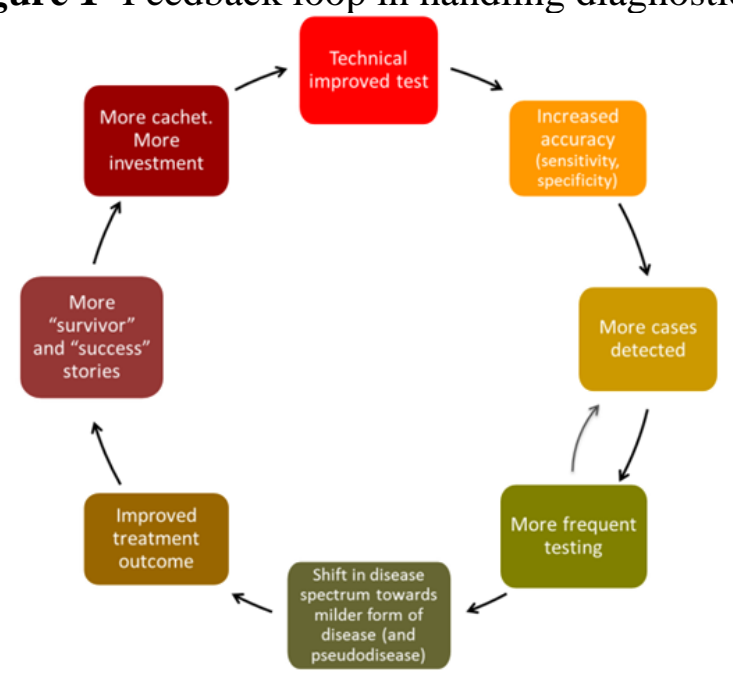

Yet another effect that tends to influence rational handling of technology is the fact that specific diseases and technologies differ in status and prestige. In particular, diseases (and the corresponding specialties) that are organ-specific, action oriented, acute, and involve the application of advanced technology have higher prestige than others $(107,108)$. This can be called Prestige bias and may certainly result in non-rational handling of technology, for instance in excessive use of technology because it can increase the prestige of the disease. It tends to make us reluctant to disinvest in anything that is associated with progress, action, and control.

Another such tendency is identified as an Imperative of Action: action is better than inaction. This imperative can be recognized in the traditional medical phrase ut uliquid fiat (something must happen). Modern health care, and technology in particular, is strongly connected to action, intervention and control, and reducing readiness to do so can be conceived of as undermining professional integrity. Withholding and withdrawal of technology use appears to 
be difficult, when technology is available, even if it is futile (109). This Imperative of Action can be connected to the tendency to use technology as a placebo.

It is well known that technology boosts the placebo effect (110-112). As pointed out already, diagnostic technology is used therapeutically, and sometimes somatic diagnostic technology (imaging) is applied to treat mental conditions in physicians (fear of litigation). When this Technology Placebo Effect is a great part of the total outcome compared to the documented (placebo-controlled) effect it may become important for handling medical technology (113). This may explain the extensive use of a wide range of low-value care, including several kinds of surgery (112), and it can hamper or undermine rational handling of technology.

A related imperative is fostered by professionals experiencing a series of new technologies entering their professional scene all the time. Professionals experience a continuous progress as new methods and technologies relentlessly enter the professional scene. This is partly because technology is associated with innovation, action, control, progress, and optimism (114-117) and is related to the Technology Placebo Effect and Progress bias.

Correspondingly, any efforts to hamper this forward-flow of advancement appear regressive and counterintuitive and an incorrect way to handle technology. In the field of diagnostics this is expressed as an Imperative of Knowledge, e.g., in terms of that "to know is better than not to know." While knowledge certainly can be a good thing in health care, false positives, incidental findings, ambiguous and uncertain results, and overdiagnosis undermine the universality of this benefit. Related to the Imperative of Knowledge is the strong belief that early is better than late. Detecting and treating disease early is better than detecting it late. One result of this Imperative of the primus is that we tend to think that early detection is better than late (118). Accordingly, to reduce technologies for early detection and treatment appears counterintuitive and opposes professional norms and values (119). This presupposes a specific (linear progressive) conception of disease development that by far holds for all diseases.

Another imperative is related to the need of training and education: the Competency Effect. Professionals need to practice in order to obtain and maintain skills in the use of specific technologies. This results in diagnostic and therapeutic procedures sometimes being performed more for the sake of professionals than for patients (120). Procedures performed for professionals and not for patients counter rational handling of technology as stated in HTA, priority setting, and health policy documents.

Other effects that counter rational handling of technology can be observed in everyday clinical practice. One example of this is what can be called Double (or multiple)

replacement. For example, it is strongly argued to replace an ultrasound machine because it is "outdated," "provides low quality images," or "is dangerous." However, when the new machine arrives, the old machine is kept as a backup, and after some time, the old machine reenters the daily practice, for example because of high demand. After a while, it is argued again that it is "outdated," "provides low quality images," and "is dangerous” and needs replacement. This effect can be related to Roemer's law and the Extension bias.

Yet another phenomenon is what has been called "White Elephants."” These are technologies that are implemented in order to attract proficient professionals, to keep specific health professionals happy, or to attract patients, but where the technology may not be of any or little value to patients' outcome. Regrettably, many technologies have been bought and maintained for many years without ever being used. Monitoring devices as well as surgical lasers have become deserted when specific professionals leave for new positions. In anesthetics the trends have swung between inhalation anesthesia and intravenous anesthesia

\footnotetext{
${ }^{2}$ The term «white elephants» stems from South-East Asia, where white elephants were considered to be holy, and thus neither could work nor be killed.
} 
for decades, with local variations very much depending on context $(121,122)$. This generates opportunity costs and challenges rational handling of medical technology.

Moreover, there are many technologies that have been implemented because of their attractiveness to professionals and patients and not because of their effectiveness or efficiency. Surgery robots are but one example that are widely implemented and used without documented effect on reduced mortality or morbidity (123-125). This "Boys and Toys Effect” can be related to the fact that the requirements for documented effectiveness and efficiency has been different for devices than for drugs (16).

Table 4 summarizes the biases and imperatives identified in this study. 
Table 4 Overview of various biases, imperatives, and rational handling of technology

\begin{tabular}{|c|c|c|}
\hline Biases (System 1) & Imperative & System 2 \\
\hline $\begin{array}{l}\text { Affective biases } \\
\text { Identifiability Effect } \\
\text { Affective Forecasting } \\
\text { Aversion to risk } \\
\text { Aversion to ambiguity } \\
\text { Technology Optimism }\end{array}$ & \multirow{2}{*}{$\begin{array}{l}\text { Roemer's law } \\
\text { Progress Bias } \\
\text { Adoption Addiction } \\
\text { Complexity Bias } \\
\text { Extension Bias } \\
\text { Positive feedback loops } \\
\text { Prestige bias } \\
\text { Imperative of Action } \\
\text { Technology Placebo Effect } \\
\text { Imperative of Knowledge } \\
\text { Imperative of the Primus } \\
\text { Competency Effect } \\
\text { Multiple Replacements } \\
\text { White Elephants } \\
\text { Boys and Toys Effect }\end{array}$} & $\begin{array}{l}\text { Rational handling of } \\
\text { technology, according to } \\
\text { documented evidence for } \\
\text { effectiveness, cost- } \\
\text { effectiveness/efficiency, }\end{array}$ \\
\hline $\begin{array}{l}\text { Cognitive biases } \\
\text { Focusing Illusion } \\
\text { Prominence Effect } \\
\text { Status Quo Bias } \\
\text { Endowment Effect } \\
\text { Availability Heuristics } \\
\text { Loss Aversion } \\
\text { Anchoring Effect } \\
\text { Better safe than sorry } \\
\text { Aversion to Risk or Ambiguity }\end{array}$ & & $\begin{array}{l}\text { Principles for priority } \\
\text { setting (severity, } \\
\text { effectiveness, efficiency, } \\
\text { equity, solicarity) } \\
\text { Methods and guidelines } \\
\text { for HTA, Health Policy } \\
\text { Making }\end{array}$ \\
\hline
\end{tabular}

\section{Discussion}

Hence, there are a wide range of affective and cognitive biases that may counter rational handling of technology, as expressed in foundational documents for HTA, priority setting and health policy making. Additionally, a series of imperatives that may do the same have been identified.

However, many more than have been discussed here are relevant for the handling of medical technology (126). Certainly, social pressures frequently studied in Human Relations may be relevant, e.g., Bandwagoning (127). The same goes for Context Errors, which are well known from clinical decision making. For example, when the physician is not able to see the context of the patient's condition and makes erroneous diagnostic or therapeutic judgements (126).

Nonetheless, the intention has not been to provide an exhaustive list of biases and imperatives, but more modest to give some examples to illustrate how biases and imperatives can affect the handling of technology in different ways. The classification of affective and cognitive biases and imperatives is not strict. Certainly, there are close connections between all of these. E.g., there is a close connection between Technology Optimism (classified as affective) and Progress Bias (classified as cognitive), between Aversion to Risk and Loss aversion and so on. However, the intention has not been to dive into the diverse and detailed debates on the classification and relationship between affective and cognitive biases. Rather it has been to point to some effects that seem relevant for rational handling of medical technology.

Besides, there are close connections between imperatives and both System- 1 and System-2 modes of thinking. For example, various types of System-1-biases may underlie the imperatives, e.g., various types of framing-effects can contribute in the various imperatives. Correspondingly, information bias (60) may underlie the Imperative of Knowledge. As already pointed out, some of the imperatives also are named "biases."

Likewise, the biases and imperatives that have been described here may be classified, analyzed, and explained in a wide range of other ways, for example as inertia (128-131), as technological imperatives or drivers $(31,35,38,97)$ or as human deficiencies (132). Again, 
the point has not been to develop a specific typology or nomenclature, but to increase the awareness of the phenomena and how they influence the handling of medical technologies. Moreover, the various effects that have been studied have not been placed within specific theoretical frameworks. Clearly, many of the effects can be explained by conceptualmetaphorical theory (102), as vices of the mind (133), conflict of interests (134), or other theories. However, theoretical framing is beyond the scope of this study. One reason why this study is not exhaustive is that handling technology itself is a complex issue. To investigate to what extent the various effects hamper various parts of handling technology and how they interact in detail is well beyond the scope of this study. Nonetheless, this indicates the next and important steps for research: to investigate how the various types of biases and imperatives influence the different levels and stages of handling technology, such as (e.g., development, assessment, appraisal, decision making, implementation, use, disinvestment, or health policy making.

Nonetheless, this study provides the first step to addressing the issue: to identify it. To reveal, acknowlede, analyze, and address the various non-rational ways of handling technologies is a necessary step to address the issue.

It may of course be argued that it is not possible to eliminate biases (135) and that one instead should revise the scope, goal, principles, regulations, criteria, and norms for handling technology. Again, this is an important question, but it is beyond the scope of this article. Besides, there are important measures available already, such as debiasing (127) (136-138), decision support (139-141) and interventions to improve clinical decision-making skills (142). It is also important to notice that I have neither given an objective account of what is considered to be rational handling of technology, nor have I defined the term. I have much more modestly applied the term as it is used in medicine and health care itself, and most particular how it is expressed in basic documents for HTA, priority setting, and health policy making. This conception of "rational handling of technology" is closely connected to what has been called Evidence Based Medicine (EBM), relying on a specific kind of rationality $(143,144)$. It is clearly beyond scope to enter the interesting and important debates on rationality $(145)$ and $\operatorname{EBM}(144,146)$. The point here is merely to take the basic conception of rational handling of technology at face value.

Although research from cognitive psychology and behavioral economics has become widely acknowledged, they may not yet be practically integrated in health policy making. This article has not been able to go into the details of all the biases and imperatives and the many theories that can be used to understand and handle them. However, a wide range of basic phenomena, explanations and examples have been provided, as well as an extensive number of references in order to help the reader to pursue the various issues discussed in this article, which is meant to be a brief overview of an important and partly ignored challenge to handling technology in health policy making.

\section{Conclusion}

Medical technology has widely been conceived of as a rational science-based means to obtain specific human goals, such as reducing suffering and increasing health. However, there are many examples that we are not handling medical technology as rational as core stakeholders in the field appear to think. By using the framework of System-1 and System-2 thinking of Kahneman and the framework of imperatives by Mazarr, I have tried to investigate this nonrational handling of medical technologies in terms of biases and imperatives. If my analysis is reasonable, then it challenges the way we handle medical technology in health care today. Moreover, it poses challenges technology theories that do not encompass emotional and 
cognitive biases as well as imperatives. Understanding technology indeed includes understanding of ourselves.

\section{References}

1. Hofmann B, Bond K, Sandman L. Evaluating facts and facting evaluations: On the fact-value relationship in HTA. Journal of evaluation in clinical practice. 2018;24(5):957-65.

2. International Network of Agencies for Health Technology Assessment. Technology Assessment. International Network of Agencies for Health Technology Assessment; 2011.

3. (OTA). OoTA. Development of medical technologies: Opportunities for assessment. Washington, DC: United States Congress; 1976.

4. Banta HD, Perry S. A history of ISTAHC. A personal perspective on its first 10 years. International Society of Technology Assessment in Health Care. International journal of technology assessment in health care. 1997;13(3):430-53; discussion 54-62.

5. Daniels N, Sabin J. Limits to health care: fair procedures, democratic deliberation, and the legitimacy problem for insurers. Philosophy \& public affairs. 1997;26(4):303-50.

6. Cookson R, Dolan P. Principles of justice in health care rationing. Journal of medical Ethics. 2000;26(5):323-9.

7. World Health Organization. WHA67. 23-Health intervention and technology assessment in support of universal health coverage. The Sixty-seventh World Health Assembly 24. Geneva: WHA Resolution; 2014.

8. Cutcliffe SH. The STS curriculum: What have we learned in twenty years? Science, Technology, \& Human Values. 1990;15(3):360-72.

9. Feenberg A. Critical theory of technology: Oxford University Press New York; 1991.

10. Hanks C. Technology and values: Essential readings: John Wiley \& Sons; 2009.

11. Jasanoff $\mathrm{S}$. Constitutional moments in governing science and technology. Science and engineering ethics. 2011;17(4):621-38.

12. Tunis SR. Reflections on science, judgment, and value in evidence-based decision making: a conversation with David Eddy. Health Affairs. 2007;26(4):w500-w15.

13. Hofmann B. On value-judgements and ethics in health technology assessment. Poiesis \& Praxis. 2005;3(4):277-95.

14. Hofmann B, Cleemput I, Bond K, Krones T, Droste S, Sacchini D, et al. Revealing and acknowledging value judgments in health technology assessment. International journal of technology assessment in health care. 2014;30(6):579-86.

15. Hofmann BM. Too much technology. BMJ (Clinical research ed). 2015;350:h705.

16. Wilmshurst $P$. The regulation of medical devices. Unsatisfactory, unscientific, and in need of a major overhaul. BMJ (Clinical research ed). 2011;342:d2822.

17. Godlee F. Why aren't medical devices regulated like drugs? 2018;363.

18. Fisher ES, Welch HG. Avoiding the unintended consequences of growth in medical care: how might more be worse? JAMA : the journal of the American Medical Association. 1999;281(5):446-53.

19. Elshaug AG, Rosenthal MB, Lavis JN, Brownlee S, Schmidt H, Nagpal S, et al. Levers for addressing medical underuse and overuse: achieving high-value health care. The Lancet. 2017;390(10090):191-202.

20. Brownlee S, Chalkidou K, Doust J, Elshaug AG, Glasziou P, Heath I, et al. Evidence for overuse of medical services around the world. The Lancet. 2017;390(10090):156-68.

21. Saini V, Brownlee S, Elshaug AG, Glasziou P, Heath I. Addressing overuse and underuse around the world. The Lancet. 2017;390(10090):105-7.

22. Glasziou P, Straus S, Brownlee S, Trevena L, Dans L, Guyatt G, et al. Evidence for underuse of effective medical services around the world. The Lancet. 2017;390(10090):169-77. 
23. Parkinson B, Sermet C, Clement F, Crausaz S, Godman B, Garner S. Disinvestment and valuebased purchasing strategies for pharmaceuticals: an international review. PharmacoEconomics. 2015;33.

24. Malik H, Marti J, Darzi A, Mossialos E. Savings from reducing low-value general surgical interventions. British Journal of Surgery. 2018;105(1):13-25.

25. Dovjak P. Choosing wisely in case of hypertension, diabetes and hyperlipidemia in older patients. Wiener Medizinische Wochenschrift. 2016;166(5-6):166-72.

26. Soril LJ, Seixas BV, Mitton C, Bryan S, Clement FM. Moving low value care lists into action: prioritizing candidate health technologies for reassessment using administrative data. BMC health services research. 2018;18(1):640.

27. Paprica PA, Culyer AJ, Elshaug AG, Peffer J, Sandoval GA. From talk to action: policy stakeholders, appropriateness, and selective disinvestment. International journal of technology assessment in health care. 2015;31(4):236-40.

28. Mazarr MJ. Rethinking risk in national security: Lessons of the financial crisis for risk management: Springer; 2016.

29. Kahneman D, Tversky A. Intuitive prediction: Biases and corrective procedures. Eugene, Oregon: Decision Research; 1977.

30. Kahneman D, Slovic P, Tversky A. Judgement Under Uncertainty: Heuristics and Biases. New York: Cambridge University Press, Cambridge; 1982.

31. Barger-Lux MJ, Heaney RP. For better and worse: the technological imperative in health care. Social science \& medicine. 1986;22(12):1313-20.

32. Healey JM. Artificial feeding: controlling the "technological imperative". Connecticut medicine. 1986;50(2):135-6.

33. Hofmann B. Is there a technological imperative in health care? International journal of technology assessment in health care. 2002;18(3):675-89.

34. Koenig BA. The technological imperative in medical practice: The social creation of a "routine" treatment. Biomedicine examined: Springer; 1988. p. 465-96.

35. Mandell HN. Technological imperative. Or, when your tool is a hammer, everything looks like a nail. Postgraduate medicine. 1983;74(2):24-6.

36. Ogden RD. Non-physician assisted suicide: the technological imperative of the deathing counterculture. Death studies. 2001;25(5):387-401.

37. Rothman D. Beginnings count : the technological imperative in American health care. New York: Oxford University Press; 1997.

38. Wolf S, Berle B. The Technological Imperative in Medicine. New York: Plenum Press; 1981.

39. Hsieh HF, Shannon SE. Three approaches to qualitative content analysis. Qualitative health research. 2005;15(9):1277-88.

40. Hayes JH, Barry MJ. Screening for prostate cancer with the prostate-specific antigen test: a review of current evidence. JAMA : the journal of the American Medical Association.

2014;311(11):1143-9.

41. Ilic D, Neuberger MM, Djulbegovic M, Dahm P. Screening for prostate cancer. The Cochrane database of systematic reviews. 2013(1):Cd004720.

42. Zahl PH, Kalager M, Suhrke $P$, Nord E. Quality-of-life effects of screening mammography in Norway. International journal of cancer. 2019.

43. Jorgensen KJ, Gotzsche PC. Breast Cancer Screening: Benefit or Harm? Jama. 2016;315(13):1402.

44. Evans DGR, Barwell J, Eccles DM, Collins A, Izatt L, Jacobs C, et al. The Angelina Jolie effect: how high celebrity profile can have a major impact on provision of cancer related services. Breast Cancer Research. 2014;16(5):442.

45. Daniels N. Reasonable disagreement about identifed vs. statistical victims. Hastings Center Report. 2012;42(1):35-45.

46. Wiss J, Andersson D, Slovic $P$, Vastfjall D, Tinghog $G$. The influence of identifiability and singularity in moral decision making. 2015. 
47. Pedersen T, Møller AM, Pedersen BD. Pulse oximetry for perioperative monitoring: systematic review of randomized, controlled trials. Anesthesia \& Analgesia. 2003;96(2):426-31.

48. Pedersen T, Nicholson A, Hovhannisyan K, Moller AM, Smith AF, Lewis SR. Pulse oximetry for perioperative monitoring. The Cochrane database of systematic reviews. 2014;3:Cd002013.

49. Ahn HS, Welch HG. South Korea's thyroid-cancer "epidemic" - turning the tide. New England Journal of Medicine. 2015;373(24):2389-90.

50. Wilson TD, Gilbert DT. Affective forecasting. Advances in experimental social psychology. 2003;35(35):345-411.

51. Morewedge CK, Buechel EC. Motivated underpinnings of the impact bias in affective forecasts. Emotion. 2013;13(6):1023.

52. Frohlich $\mathrm{H}$, Balling $\mathrm{R}$, Beerenwinkel $\mathrm{N}$, Kohlbacher $\mathrm{O}$, Kumar $\mathrm{S}$, Lengauer $\mathrm{T}$, et al. From hype to reality: data science enabling personalized medicine. BMC medicine. 2018;16(1):150.

53. Mazzanti M, Shirka E, Gjergo H, Hasimi E. Imaging, Health Record, and Artificial Intelligence: Hype or Hope? Current cardiology reports. 2018;20(6):48.

54. Fox S, Do T. Getting real about Big Data: applying critical realism to analyse Big Data hype. International Journal of Managing Projects in Business. 2013;6(4):739-60.

55. Goldfield NI. Big data-hype and promise. The Journal of ambulatory care management. 2014;37(3):195.

56. Saracci R. Epidemiology in wonderland: Big Data and precision medicine. European journal of epidemiology. 2018;33(3):245-57.

57. Otero HJ, Ondategui-Parra S, Nathanson EM, Erturk SM, Ros PR. Utilization management in radiology: basic concepts and applications. Journal of the American College of Radiology. 2006;3(5):351-7.

58. Hendee WR, Becker GJ, Borgstede JP, Bosma J, Casarella WJ, Erickson BA, et al. Addressing overutilization in medical imaging. Radiology. 2010;257(1):240-5.

59. Oren $\mathrm{O}$, Kebebew E, loannidis JPA. Curbing Unnecessary and Wasted Diagnostic Imaging. JAMA : the journal of the American Medical Association. 2019.

60. Saposnik G, Redelmeier D, Ruff CC, Tobler PN. Cognitive biases associated with medical decisions: a systematic review. BMC medical informatics and decision making. 2016;16(1):138.

61. Fryback DG, Thornbury JR. The efficacy of diagnostic imaging. Medical decision making. 1991;11(2):88-94.

62. Schkade DA, Kahneman D. Does living in California make people happy? A focusing illusion in judgments of life satisfaction. Psychological Science. 1998;9(5):340-6.

63. Krupinski EA, Jiang Y. Anniversary paper: evaluation of medical imaging systems. Medical physics. 2008;35(2):645-59.

64. Højgaard L. Are Health Technology Assessments a reliable tool in the analysis of the clinical value of PET in oncology? Who audits the auditors? : Springer; 2003.

65. McEwan A. Does health technology assessment put patient care at risk? Journal of Nuclear Medicine. 2005;46(12):1939-.

66. Tinghög G, Västfjäll D. Why People Hate Health Economics-Two Psychological Explanations. Linköping University, Division of Economics, Department of Management and Engineering; 2018.

67. Kahneman D, Tversky A. Choices, values, and frames. HANDBOOK OF THE FUNDAMENTALS OF FINANCIAL DECISION MAKING: Part I: World Scientific; 2013. p. 269-78.

68. Kahneman D, Knetsch JL, Thaler RH. Anomalies: The Endowment Effect, Loss Aversion, and Status Quo Bias. Journal of Economic Perspectives. 1991;5(1):193-206.

69. Polisena J, Clifford T, Elshaug AG, Mitton C, Russell E, Skidmore B. Case studies that illustrate disinvestment and resource allocation decision-making processes in health care: a systematic review. International journal of technology assessment in health care. 2013;29(2):174-84.

70. Daniels T, Williams I, Robinson S, Spence K. Tackling disinvestment in health care services. The views of resource allocators in the English NHS. J Health Organ Manag. 2013;27(6):762-80. 
71. Henshall C, Schuller T, Mardhani-Bayne L. Using health technology assessment to support optimal use of technologies in current practice: the challenge of "disinvestment". International journal of technology assessment in health care. 2012;28.

72. Haas M, Hall J, Viney R, Gallego G. Breaking up is hard to do: why disinvestment in medical technology is harder than investment. Aust Health Review. 2012;36.

73. Elshaug AG, Hiller JE, Tunis SR, Moss JR. Challenges in Australian policy processes for disinvestment from existing, ineffective health care practices. Aust New Zealand Health Policy. 2007;4.

74. Tymstra T. The imperative character of medical technology and the meaning of "anticipated decision regret". Int J of Technology Assessment in health Care. 1989;5:207-13.

75. Beyleveld D, Brownsword R. Emerging technologies, extreme uncertainty, and the principle of rational precautionary reasoning. Law, Innovation and Technology. 2012;4(1):35-65.

76. Welch HG, Black WC. Overdiagnosis in cancer. Journal of the National Cancer Institute. 2010;102(9):605-13.

77. Raffle A, Muir Gray J. Screening: Evidence and Practice. New York, NY: Oxford University Press; 2007.

78. Kmietowicz Z. Better safe than sorry? Bmj. 2007;335(7631):1182-4.

79. Schiodt FV, Lee WM. Liver transplantation for acute liver failure--better safe than sorry. Liver transplantation : official publication of the American Association for the Study of Liver Diseases and the International Liver Transplantation Society. 2002;8(11):1063-4.

80. Scheidt RC. Ensuring correct site surgery. AORN journal. 2002;76(5):769-77.

81. Ioannidis JP. Why most published research findings are false: author's reply to Goodman and Greenland. PLoS medicine. 2007;4(6):e215.

82. Andrade Ede O, Andrade EN, Gallo JH. Case study of supply induced demand: the case of provision of imaging scans (computed tomography and magnetic resonance) at Unimed-Manaus. Revista da Associacao Medica Brasileira (1992). 2011;57(2):138-43.

83. Bradley D, Bradley KE. The value of diagnostic medical imaging. North Carolina medical journal. 2014;75(2):121-5.

84. Shain M, Roemer MI. Hospital costs relate to the supply of beds. Journal of Occupational and Environmental Medicine. 1959;1(9):518.

85. Wennberg JE. Tracking medicine: a researcher's quest to understand health care: Oxford University Press; 2010.

86. Auster RD, Oaxaca RL. Identification of supplier induced demand in the health care sector. Journal of Human Resources. 1981:327-42.

87. Hofmann B. Progress bias in the ethics of emerging science and technology. Bioethics. 2019 Accepted.

88. Fenn J, Raskino M. Mastering the hype cycle: how to choose the right innovation at the right time. Boston: Harvard Business Press; 2008.

89. Linden A, Fenn J. Understanding Gartner's hype cycles. Strategic Analysis Report № R-201971 Gartner, Inc. 2003.

90. van de Wetering R, Batenburg R. A PACS maturity model: a systematic meta-analytic review on maturation and evolvability of PACS in the hospital enterprise. International journal of medical informatics. 2009;78(2):127-40.

91. Black AD, Car J, Pagliari C, Anandan C, Cresswell K, Bokun T, et al. The impact of eHealth on the quality and safety of health care: a systematic overview. PLoS medicine. 2011;8(1):e1000387.

92. Anton MT, Jones DJ. Adoption of technology-enhanced treatments: conceptual and practical considerations. Clinical Psychology: Science and Practice. 2017.

93. Greenhalgh T, Wherton J, Papoutsi C, Lynch J, Hughes G, A'Court C, et al. Beyond Adoption: A New Framework for Theorizing and Evaluating Nonadoption, Abandonment, and Challenges to the Scale-Up, Spread, and Sustainability of Health and Care Technologies. Journal of medical Internet research. 2017;19(11):e367. 
94. Scotland G, Bryan S. Why Do Health Economists Promote Technology Adoption Rather Than the Search for Efficiency? A Proposal for a Change in Our Approach to Economic Evaluation in Health Care. Medical decision making : an international journal of the Society for Medical Decision Making. 2017;37(2):139-47.

95. Bryan S, Mitton C, Donaldson C. Breaking the addiction to technology adoption. Health Econ. 2014;23.

96. Sia S. Justification and radiology: some ethical considerations. Radiat Prot Dosimetry. 2009;135(2):128-33.

97. Hofmann B. Is there a technological imperative in health care? International journal of technology assessment in health care. 2002;18(3):675-89.

98. Hofmann B. The technological invention of disease - on disease, technology and values. University of Oslo; 2002.

99. Hofmann B. When means become ends: technology producing values. Seminarnet : Media, technology and lifelong learning. 2006;2(2).

100. Rank B. Executive physicals--bad medicine on three counts. The New England journal of medicine. 2008;359(14):1424-5.

101. Welch HG, Schwartz L, Woloshin S. Overdiagnosed : making people sick in the pursuit of health. Boston, Mass.: Beacon Press; 2011. xvii, 228 p. p.

102. Lakoff G, Johnson. M. Philosophy in the Flesh. New york: Basic books; 1999.

103. Slovic $P$, Peters E. Risk perception and affect. Current directions in psychological science. 2006;15(6):322-5.

104. Slovic P. The perception of risk. London: Routledge; 2016.

105. Gigerenzer G. Calculated risks: How to know when numbers deceive you: Simon and Schuster; 2015.

106. Black WC, Welch HG. Advances in diagnostic imaging and overestimations of disease prevalence and the benefits of therapy. The New England journal of medicine. 1993;328(17):1237-43.

107. Album D, Johannessen LE, Rasmussen EB. Stability and change in disease prestige: A comparative analysis of three surveys spanning a quarter of a century. Social science \& medicine. 2017.

108. Album D, Westin S. Do diseases have a prestige hierarchy? A survey among physicians and medical students. Social science \& medicine. 2008;66(1):182-8.

109. Jennett B. Medical technology, social and health care issues. In: Gillon R, editor. Principles of health care ethics. New York: Wiley; 1994. p. 861-72.

110. Saririan M, Eisenberg M. Myocardial Laser Revascularization for the Treatment of End-Stage Coromary Artery Disease. Journal of the American College of Cardiology. 2003;41(2):173-83.

111. Einvik G, Tjomsland O, Kvernebo K, Stavnes $S, \varnothing$. E. Preoperativ forventning og klinisk effekt ved transmyokardial laserbehandling mot angina pectoris. Tidsskr Nor Lægeforen. 2002;122:2102-4. 112. Harris IA. Surgery, the ultimate placebo: a surgeon cuts through the evidence: NewSouth Sydney; 2016.

113. Howard L, Wessely S, Leese M, Page L, McCrone P, Husain K, et al. Are investigations anxiolytic or anxiogenic? A randomised controlled trial of neuroimaging to provide reassurance in chronic daily headache. Journal of neurology, neurosurgery, and psychiatry. 2005;76(11):1558-64.

114. Fredriksen S. Tragedy, utopia and medical progress. J Med Ethics. 2006;32(8):450-3.

115. Haas M, Hall J, Viney R, Gallego G. Breaking up is hard to do: why disinvestment in medical technology is harder than investment. Australian health review : a publication of the Australian Hospital Association. 2012;36(2):148-52.

116. Strand R, Saltelli A, Giampietro M, Rommetveit K, Funtowicz S. New narratives for innovation. Journal of Cleaner Production. 2016(197):1849-53.

117. Greenhalgh T. Five biases of new technologies. Br J Gen Pract. 2013;63(613):425.

118. Hofmann B, Skolbekken JA. Surge in publications on early detection. BMJ (Clinical research ed). 2017;357:j2102.

119. Stempsey WE. Disease and Diagnosis: Value-dependant Realism. Dortrecht: Kluwer; 1999. 
120. lacobucci G. NHS proposes to stop funding 17 "unnecessary" procedures. BMJ. 2018;362.

121. Lundy JS, Adams RC, Seldon TH. Factors influencing trends in anesthesia. Surgery.

$1945 ; 18(1): 1-7$.

122. Egan TD. Total intravenous anesthesia versus inhalation anesthesia: a drug delivery perspective. Journal of cardiothoracic and vascular anesthesia. 2015;29 Suppl 1:S3-6.

123. Abrishami P, Boer A, Horstman K. Understanding the adoption dynamics of medical innovations: affordances of the da Vinci robot in the Netherlands. Social science \& medicine. 2014;117:125-33.

124. Authority HlaQ. Health technology assessment of robot-assisted surgery in selected surgical procedures. Cork: Health Information and Quality Authority; 2012.

125. Kim CW, Kim CH, Baik SH. Outcomes of robotic-assisted colorectal surgery compared with laparoscopic and open surgery: a systematic review. Journal of Gastrointestinal Surgery. 2014;18(4):816-30.

126. Wright $B$, Bragge $P$. What strategies to review diagnoses are feasible and sustainable in Emergency Departments? Melbourne, Australia: BehaviourWorks Australia, Monash University; 2017 [

127. Cantarelli P, Belle N, Belardinelli P. Behavioral Public HR: Experimental Evidence on Cognitive Biases and Debiasing Interventions. Review of Public Personnel Administration. 2018:0734371X18778090.

128. Saposnik G, Montalban X. Therapeutic inertia in the New Landscape of Multiple sclerosis care. Frontiers in neurology. 2018;9:174.

129. Okonofua EC, Simpson KN, Jesri A, Rehman SU, Durkalski VL, Egan BM. Therapeutic inertia is an impediment to achieving the Healthy People 2010 blood pressure control goals. Hypertension. 2006;47(3):345-51.

130. Cooke CE, Sidel M, Belletti DA, Fuhlbrigge AL. clinical inertia in the management of chronic obstructive pulmonary disease. COPD: Journal of Chronic Obstructive Pulmonary Disease. 2012;9(1):73-80.

131. Reach G, Pechtner V, Gentilella R, Corcos A, Ceriello A. Clinical inertia and its impact on treatment intensification in people with type 2 diabetes mellitus. Diabetes \& metabolism. 2017. 132. Cassell E. The Sourcer's Broom. Medicine's Rampant Technology. Hastings Center Report. 1993;23(6):32-9.

133. Cassam Q. Vices of the Mind: From the Intellectual to the Political: Oxford University Press; 2018.

134. Gander JC, Zhang X, Ross K, Wilk AS, McPherson L, Browne T, et al. Association Between Dialysis Facility Ownership and Access to Kidney Transplantation. JAMA : the journal of the American Medical Association. 2019;322(10):957-73.

135. Wieringa S, Engebretsen E, Heggen K, Greenhalgh T. Rethinking bias and truth in evidencebased health care. Journal of evaluation in clinical practice. 2018.

136. Croskerry P, Singhal G, Mamede S. Cognitive debiasing 1: origins of bias and theory of debiasing. BMJ Qual Saf. 2013:bmjqs-2012-001712.

137. Wilson TD, Brekke N. Mental contamination and mental correction: unwanted influences on judgments and evaluations. Psychological bulletin. 1994;116(1):117.

138. Croskerry P, Singhal G, Mamede S. Cognitive debiasing 2: impediments to and strategies for change. BMJ Qual Saf. 2013;22(Suppl 2):ii65-ii72.

139. Newman-Toker DE, Pronovost PJ. Diagnostic errors - the next frontier for patient safety. Jama. 2009;301(10):1060-2.

140. Lee CS, Nagy PG, Weaver SJ, Newman-Toker DE. Cognitive and system factors contributing to diagnostic errors in radiology. American Journal of Roentgenology. 2013;201(3):611-7.

141. McDonald KM, Matesic B, Contopoulos-loannidis DG, Lonhart J, Schmidt E, Pineda N, et al. Patient safety strategies targeted at diagnostic errors: a systematic review. Annals of internal medicine. 2013;158(5_Part_2):381-9. 
142. Graber ML, Kissam S, Payne VL, Meyer AN, Sorensen A, Lenfestey N, et al. Cognitive interventions to reduce diagnostic error: a narrative review. BMJ Qual Saf. 2012:bmjqs-2011-000149.

143. De Simone J. Beyond 'faith-based medicine' and EBM. Journal of evaluation in clinical practice. 2006;12(4):438-44.

144. Greenhalgh T, Howick J, Maskrey N. Evidence based medicine: a movement in crisis? BMJ (Clinical research ed). 2014;348.

145. Hilpinen R. Rationality in science: studies in the foundations of science and ethics: Springer Science \& Business Media; 2012.

146. Howick JH. The philosophy of evidence-based medicine. Oxford: Sons; 2011. 